than has any particular individual, who is more likely to be concerned only with his own benefits.

The assessment of the risks involved can, of course, rarely be a very precise procedure, as adequate data will not usually be available; but this does not mean to say that it is not a more realistic procedure than the use of some completely arbitrary and irrelevant figure such as the current 'bank rate', and in most cases the order of risk involved will be fairly clear, indicating a discount rate of, say, $1-2 \%$ or, alternatively, $3-5 \%$ or even $10-15 \%$.

\section{SUMMARY}

The use of current money-lending rates as the basis for economic calculations involving long-term assets such as growing timber, agricultural land, or species of wildlife, is unrealistic and can be very damaging to the interests of the environment. An alternative method, using an assessment of risks together with an assessment of the expected ratio of investment: income, is proposed.

\section{References}

Helliwell, D. R. (1974). Discount rates in land-use planning. Forestry, 47(2), pp. 147-52.

Linstone, H. A. (1973). On discounting the future. Technological Forecasting and Social Change, 4, pp. 335-8.

McEwan, L. V. (1971). Capital in Scottish agriculture. Scottish Agricultural Economics, 21, pp. 17-24.

PRICE, C. (1973). To the future: with indifference or concern ?The social discount rate and its implications in land use. J. Agric. Econ., 24, pp. 393-7.

SARGENT, T. J. (1972). Antricipated inflation and the nominal rate of interest. Quarterly Journal of Economics, 86, pp. 212-5.

\title{
Airlines for Nature Conservation
}

Austrian Airlines, Britannia Airways, CP Air, Eastern Provincial Airways, Quebecair, Pakistan International Airlines, and Spantax, have recently given their support to World Wildlife Fund resolutions on nature conservation, bringing the total number of such adherents to 70 .

The Resolutions, passed in 1971 and 1974 by the Board of Trustees of the World Wildlife Fund under the Presidency of H.R.H. The Prince of the Netherlands, called on airlines to commit themselves to nature conservation, not to sponsor expeditions to hunt species that are threatened with extinction, and not to carry them as freight in contravention of national bans or the Washington Convention on International Trade in Endangered Species which finally came into force on 1 July 1975. The supporting airlines and their countries are as follows:

WWF Resolutions on Conservation: Adhering Airlines and Their Countries

\begin{tabular}{ll}
\hline Country & Supporting Airlines \\
\hline Algeria & Air Algérie \\
Argentina & Aerolineas Argentinas \\
Australia & Ansett Airlines of Australia \\
& East-West Airlines \\
& Qantas \\
& Trans Australia Airlines \\
Austria & Austrian Airlines \\
Belgium & Sabena \\
Brazil & Servicos Aereos Cruziero do Sol \\
& Varig \\
Canada & Viacao Aereas São Paulo VASP \\
& Air Canada \\
& CP Air \\
Chile & Eastern Provincial Airways \\
& Quebecair \\
Colombia & Lan Chile \\
Cyprus & Linea Aerea de Cobre Chile \\
Denmark & Aerovias Nacionales \\
Ethiopia & Cyprus Airways \\
Finland & Sterling Airways \\
France & Ethiopian Airlines \\
& Finnair \\
Germany & Air France \\
Greece & UTA \\
Great Britain & Lufthansa \\
Iceland & Olympic Airways \\
& British Airways (BEA/BOAC) \\
& Britannia Airways \\
& Flugfelag Islands \\
&
\end{tabular}

\begin{tabular}{ll}
\hline Country $($ contd $)$ & Supporting Airlines (contd) \\
\hline India & Air India \\
& Indian Airlines \\
Indonesia & Garuda Indonesian Airlines \\
Iran & Iran National Airlines \\
Israel & El Al \\
Italy & Alitalia \\
Ivory Coast & Air Afrique \\
Jordan & ALIA - Royal Jordanian Air- \\
& lines \\
Kuwait & Kuwait Airways Corporation \\
Lebanon & Middle East Airlines \\
& Trans Mediterranean Airways \\
Luxembourg & Luxair \\
Malawi & Air Malawi \\
Malaysia & Malaysian Airlines \\
Malta & Malta Airlines \\
Mexico & Aeronaves de Mexico \\
Netherlands & KLM \\
New Zealand & New Zealand National Airways \\
Nigeria & Nigerian Airways \\
Pakistan & PIA \\
Papua New Guinea & Ansett Airlines of Papua New \\
Scandinavia & Guinea \\
Singapore & SAS \\
South Africa & Singapore Airlines \\
Spain & Commercial Airways \\
Sri Lanka & South African Airways \\
Switzerland & Spantax \\
Taiwan & Air Ceylon \\
Thailand & Swissair \\
Tunisia & China Airlines \\
Venezuela & Air Siam \\
Vietnam & Tunis Air \\
West Indies & Linea Aeropostal Venezolana \\
USA & Air Vietnam \\
& British West Indian Airways \\
Zaire & American Airlines \\
Zambia & Delta Airlines \\
\hline & Eastern Airlines \\
& Pan American \\
Trans World Airlines \\
Air Zaïre \\
Zambian Airways \\
\hline
\end{tabular}

Peter F. R. JACKson, Director of Information World Wildlife Fund

1110 Morges Switzerland. 